\title{
FAKTOR-FAKTOR YANG BERHUBUNGAN DENGAN KEJADIAN PREEKLAMPSIA PADA IBU BERSALIN DI RUANG BERSALIN RSUD SINGAPARNA MEDIKA CITRAUTAMA TASIKMALAYA
}

\author{
Qanita Wulandara ${ }^{1}$, Siti Patimah ${ }^{1}$ \\ ${ }^{1}$ Jurusan Kebidanan, Politeknik Kesehatan Kemenkes Tasikmalaya, Indonesia
}

\begin{abstract}
Info Artikel Abstrak
Genesis Naskah:

Submissions: 27-10-2020

Revised: $18-11-2020$

Accepted: 18-11-2020

Kata Kunci:

Ibu bersalin, Kadar

Kalsium, Obesitas,

Preeklampsia

Preeklampsia merupakan suatu keadaan tekanan darah tinggi yang disertai dengan protein urine. Sepuluh juta wanita mengalami preeklamsia setiap tahun di seluruh dunia Preeklampsia di Indonesia menjadi salah satu penyebab kematian ibu, walaupun etiologi pasti preeklampsia tidak diketahui, namun banyak faktor yang diduga mempengaruhi terjadinya preeklampsia Tujuan penelitian ini adalah untuk mengetahui faktor-faktor yang berhubungan dengan kejadian preeklampsia pada ibu bersalin di ruang bersalin RS Singaparna Medika Citrautama (SMC) Kabupaten Tasikmalaya seperti usia, paritas, obesitas, suplementasi kalsium dan kadar kalsium dalam darah. Rancangan penelitian menggunakan case control study. Subyek penelitian adalah ibu bersalin yang dibagi menjadi 2 kelompok yaitu preeklamsia dan tidak preeklampsia. Analisis data bivariat menggunakan chi-square sedangkan analisis data multivariat menggunakan regresi logistic. Hasil penelitian diperoleh bahwa terdapat hubungan signifikan antara usia $(p=0,043)$, obesitas $(p=0,038)$ dan kadar kalsium $(\mathrm{p}=0,002)$ tehadap preeclampsia dan tidak ada hubungan antara paritas $(\mathrm{p}=0,438)$ dan riwayat kesehatan yang lalu $(\mathrm{p}=1,000)$. Kesimpulan dari penelitian ini adalah ada hubungan yang signifikan antara faktor usia,obesitas dan kadar kalsium dalam darah dengan kejadian Preeklampsia. Penelitian ini merekomendasikan tenaga kesehatan untuk meningkatkan promotif dan preventif dengan penyuluhan dan sosialisasi mengenai faktor risiko kejadian preeklampsia sehingga ibu dapat menjalani kehamilan dan persalinan yang sehat.
\end{abstract}

\section{FACTORS ASSOCIATED WITH THE INCIDENCE OF PREECLAMPSIA IN PARTURIENT WOMEN AT LABOUR ROOM OF SINGAPARNA MEDIKA CITRAUTAMA HOSPITAL TASIKMALAYA}

\section{Keywords: \\ Calcium Levels, Obesity, \\ Parturient, Preeclampsia} \begin{abstract}
Preeclampsia in Indonesia is one of the causes of maternal death, although the exact etiology of preeclampsia is unknown, there are several factors that influence the occurrence of preeclampsia, namely age, parity, obesity, calcium supplementation and blood calcium levels. The purpose of this study was to determine the factors associated with the incidence of preeclampsia in parturient at labour room of SMC Hospital, Tasikmalaya Regency. The research design used case control study. The subjects of the study were parturient women that divided into 2 groups, preeclampsia and non-preeclampsia. Bivariate data analysis used chi-square, while multivariate data analysis used logistic regression. The results showed that there was a significant relationship between age $(p=0.043)$, obesity $(p=0.038)$ and calcium levels $(p=0.002)$ on preeclampsia and there was no relationship between parity $(p=0.438)$ and past medical history $(p=1,000)$. This study recommends health workers to improve promotive and preventive activities by providing counseling and socialization regarding risk factors for the incidence of preeclampsia so that mothers can have a healthy pregnancy and childbirth.
\end{abstract}

\section{Korespondensi Penulis:}

Qanita Wulandara

Jl. Cilolohan no 35 Tasikmalaya, Indonesia

Email: qanita.wulandara@dosen.poltekkestasikmalaya.ac.id 


\section{PENDAHULUAN}

Preeklampsia di Indonesia menjadi salah satu penyebab kematian ibu, Angka Kematian Bayi (AKB) di Indonesia pada tahun 2015 mencapai 23/1000 kelahiran hidup dan Angka Kematian Ibu (AKI) mencapai kisaran 305/100.000 kelahiran hidup. Penyebab angka kematian ibu selama tiga tahun terakhir menurut kemenkes RI tahun 2017 adalah sebagai akibat komplikasi kehamilan, persalinan atau masa nifas seperti preklampsia (25\%), perdarahan $(19,3 \%$ biasanya perdarahan postpartum), infeksi (15\%), partus macet (8\%), komplikasi abortus (13\%) dan sebab lain $(8 \%)$.

Penyebab Preeklampsia dan eklampsia sampai saat ini belum diketahui secara pasti, tetapi ada beberapa faktor yang mempengaruhi terjadinya Preeklampsia dalam kehamilan yaitu primigravida terutama primigravida muda, usia $>35$ tahun atau $<20$ tahun, penyakit medis yang menyertai kehamilan seperti hipertensi kronik dan diabetes mellitus. Menurut penelitian Utama tahun 2017, faktor predisposisi Preeklampsia adalah nullipara, obesitas, usia > 35 tahun, faktor genetik dan faktor lingkungan. Dari beberapa faktor yang ada faktor usia, status gravida, kenaikan berat badan merupakan faktor yang dapat dikurangi atau dicegah dengan diagnosis dini dan pengobatan segera. Dalam kepustakaan frekuensi dilaporkan berkisar antara 3-10\% pada primigravida frekuensi Preeklampsia lebih tinggi bila dibandingkan dengan multigravida, terutama primagravida muda, diabetes mellitus, mola hidatidosa, kehamilan ganda, hidrops fetalis, usia lebih dari 35 tahun dan obesitas merupakan faktor predisposisi untuk terjadinya Preeklampsia (Astuti, 2015, pp. 71-79).

Dampak yang diakibatkan dari kehamilan Preeklampsia bagi ibu adalah mengalami keguguran, gagal ginjal, pembengkakan paru-paru, pendarahan otak, pembekuan darah intravaskuler dan eklampsia. Pada bayi Preeklampsia dapat mencegah plasenta mendapat asupan darah yang cukup sehingga bayi dapat kekurangan oksigen (hypoxia) dan makanan. Komplikasi yang sering ditemukan pada Preeklampsiaeklampsia antara lain: BBLR, IUFD, asfiksia neonatorum, perdarahan pasca persalinan, kematian neonatal dini dan komplikasi lainnya (Astuti, 2015).
Rumah Sakit Singaparna Medika Citrautama (SMC) merupakan salah satu rumah sakit di Kabupaten Tasikmalaya, dari data yang diperoleh di Ruang bersalin pada tahun 2017 didapatkan jumlah ibu bersalin dengan sectio caesaria (SC) mencapai 433 kasus (32\%), sedangkan persalinan pervaginam mencapai 917 orang $(68 \%)$. Dari ibu bersalin tersebut sebanyak 172 (13\%) kasus persalinan dengan Preeklampsia. Pada tahun 2018 kasus ibu bersalin Preeklampsia mencapai 425 kasus (19\%).

Berdasarkan uraian tersebut, maka penulis tertarik untuk melakukan penelitian mengenai faktor-faktor yang berhubungan dengan kejadian preeklampsia pada ibu bersalin di Ruang bersalin RS SMC Tasikmalaya.

\section{METODE}

Jenis penelitian yang digunakan dalam penelitian ini adalah penelitian observasional analitik dengan rancangan kasus control (case control) (Notoatmodjo, 2010).

Pada penelitian ini, peneliti ingin melihat faktor-faktor yang berhubungan dengan kejadian preeklampsia pada ibu bersalin di Ruang bersalin RS SMC Tasikmalaya seperti usia, paritas, obesitas, suplementasi kalsium dan kadar kalsium dalam darah. Sampel dalam penelitian ini adalah ibu bersalin di RS SMC Kabupaten Tasikmalaya tahun 2019 sejumlah 80 orang, yaitu 40 orang untuk kelompok kasus dan 40 orang untuk kelompok kontrol.

Instrumen yang digunakan dalam penelitian ini adalah format isian atau kuesinor untuk menilai usia, paritas, obesitas, riwayat kesehatan yang lalu dan format observasi untuk menilai tekanan darah, protein urine dan kadar kalsium darah pada ibu bersalin. Analisis data bivariat menggunakan chi-square sedangkan analisis data multivariat menggunakan regresi logistik. 
HASIL

Tabel 1. Distribusi Frekuensi Karakteristik Ibu Bersalin di Ruang Bersalin RS SMC Tasikmalaya

\begin{tabular}{lcc}
\hline \multicolumn{1}{c}{ Variabel } & Frekuensi & Presentase \\
\hline Usia & & \\
\hline Berisiko & 16 & $26,7 \%$ \\
\hline Tidak berisiko & 44 & $73,3 \%$ \\
\hline Paritas & & \\
\hline Berisiko & 29 & $48,3 \%$ \\
\hline Tidak berisiko & 31 & $51,7 \%$ \\
\hline Obesitas & & \\
\hline Ya & 10 & $16,7 \%$ \\
\hline Tidak & 50 & $83,3 \%$ \\
\hline
\end{tabular}

\begin{tabular}{lcc}
\hline $\begin{array}{l}\text { Riwayat } \\
\text { Kesehatan }\end{array}$ & & \\
\hline Berisiko & 6 & $10,0 \%$ \\
\hline Tidak berisiko & 54 & $90,0 \%$ \\
\hline Kadar kalsium & & \\
\hline Normal & 32 & $53,3 \%$ \\
\hline Tidak & 28 & $46,7 \%$ \\
\hline
\end{tabular}

Tabel 2. Hubungan Variabel dengan Kejadian Preeklampsia Pada Ibu Bersalin Di Ruang Bersalin RS SMC Tasikmalaya 2019

\begin{tabular}{|c|c|c|c|c|}
\hline \multirow{2}{*}{ Variabel } & \multicolumn{2}{|c|}{ Preeklampsia } & \multirow{2}{*}{ Total } & \multirow{2}{*}{$\begin{array}{c}\text { P- } \\
\text { Value }\end{array}$} \\
\hline & Ya & Tidak & & \\
\hline \multicolumn{5}{|l|}{ Usia } \\
\hline Beresiko & $\begin{array}{c}10 \\
(62,5 \%)\end{array}$ & $6(37,5 \%)$ & $\begin{array}{c}16 \\
(100 \%)\end{array}$ & \multirow{2}{*}{0,243} \\
\hline Tidak & $\begin{array}{c}20 \\
(45,5 \%)\end{array}$ & $\begin{array}{c}24 \\
(54,5 \%)\end{array}$ & $\begin{array}{c}44 \\
(100 \%)\end{array}$ & \\
\hline \multicolumn{5}{|l|}{ Paritas } \\
\hline Beresiko & $\begin{array}{c}13 \\
(44,8 \%)\end{array}$ & $\begin{array}{c}16 \\
(55,2 \%)\end{array}$ & $\begin{array}{c}29 \\
(100 \%)\end{array}$ & \multirow{2}{*}{0,438} \\
\hline Tidak & $\begin{array}{c}17 \\
(54,8 \%)\end{array}$ & $\begin{array}{c}14 \\
(45,2 \%)\end{array}$ & $\begin{array}{c}31 \\
(100 \%)\end{array}$ & \\
\hline \multicolumn{5}{|l|}{ Obesitas } \\
\hline $\mathrm{Ya}$ & $8(80 \%)$ & $2(20 \%)$ & $\begin{array}{c}10 \\
(100 \%)\end{array}$ & \multirow{2}{*}{0,038} \\
\hline Tidak & $22(44 \%)$ & $28(56 \%)$ & $\begin{array}{c}50 \\
(100 \%)\end{array}$ & \\
\hline \multicolumn{5}{|l|}{ Riw Kes } \\
\hline Beresiko & $3(50 \%)$ & $3(50 \%)$ & $6(100 \%)$ & \multirow[b]{2}{*}{1,000} \\
\hline Tidak & $27(50 \%)$ & $27(50 \%)$ & $\begin{array}{c}54 \\
(100 \%)\end{array}$ & \\
\hline \multicolumn{5}{|l|}{ Kalsium } \\
\hline Normal & $\begin{array}{c}22 \\
(68,8 \%)\end{array}$ & $\begin{array}{c}10 \\
(31,3 \%)\end{array}$ & $\begin{array}{c}32 \\
(100 \%)\end{array}$ & \multirow{2}{*}{0,002} \\
\hline Tidak & $\begin{array}{c}8 \\
(28,6 \%)\end{array}$ & $\begin{array}{c}20 \\
(71,4 \%)\end{array}$ & $\begin{array}{c}28 \\
(100 \%)\end{array}$ & \\
\hline
\end{tabular}

Berdasarkan hasil seleksi kandidat diperoleh variabel yang memenuhi syarat untuk masuk ke model multivariat adalah usia, obesitas, kalsium, (p-value <0,25).

Tabel 3. Model Akhir Faktor Risiko Preeklampsia Pada Ibu Bersalin Di Ruang Bersalin RS SMC Tasikmalaya 2019

\begin{tabular}{lcccc}
\hline \hline Variabel & B & Sig. & OR & CI 95\% \\
\hline Usia & 1,033 & 0,185 & 2,811 & $0,6-13$ \\
Obesitas & 1,716 & 0,077 & 5,562 & $0,8-37,3$ \\
Kalsium & 1,979 & 0,008 & 7,237 & $1,7-31,3$ \\
\hline \hline
\end{tabular}

\section{PEMBAHASAN}

\section{A. Hubungan usia dengan kejadian preeklampsia pada ibu bersalin di Ruang Bersalin RS SMC Tasikmalaya}

Usia merupakan bagian dari status reproduksi yang penting. Usia berkaitan dengan peningkatan atau penurunan fungsi tubuh sehingga mempengaruhi status kesehatan. Menurut teori yang ada preeklampsia lebih sering didapatkan pada masa awal dan akhir usia reproduktif yaitu usia remaja atau diatas 35 tahun.

Tabel 1 menjelaskan bahwa dari 16 responden yang usianya termasuk berisiko (usia kehamilan $>20$ tahun dan $<35$ tahun), $10(62,5 \%)$ orang diantaranya mengalami kejadian preeclampsia sedangkan $6 \quad(37,5 \%)$ lainnya tidak mengalami preeclampsia, dan dari 44 responden yang usianya termasuk dalam kategori tidak berisiko, 20 (45,5\%) orang diantaranya mengalami kejadian preeclampsia sedang $24(54,5 \%)$ orang tidak mengalami preeclampsia. Adapun nilai $\mathrm{p}$-value yang diperoleh sebesar 0,043 lebih kecil dari 0,05 yang artinya terdapat hubungan antara usia dengan kejadian preeklampsia pada ibu bersalin. Hal ini sesuai dengan penelitian yang dilakukan oleh Langelo (2013) di RSKD Ibu dan Anak Siti Fatimah Makassar yang membuktikan bahwa usia merupakan salah satu faktor risiko dominan yang berhubungan dengan kejadian preeklampsia dengan $\mathrm{OR}=2,492$ yang artinya ibu hamil pada usia yang berisiko, berisiko 2,492 kali terkena preeklampsia dibandingkan pada kelompok usia yang tidak berisiko. 


\section{B. Hubungan paritas dengan kejadian preeklampsia pada ibu bersalin di Ruang Bersalin RS SMC Tasikmalaya}

Berdasarkan tabel 2 dapat dilihat bahwa nilai $\mathrm{p}=0,438$, yaitu $>0,05$ sehingga dapat disimpulkan bahwa tidak terdapat hubungan antara paritas dengan kejadian preeklampsia pada ibu bersalin. Persalinan yang berulang akan mempunyai banyak resiko terhadap kehamilan, telah terbukti bahwa persalinan kedua dan ketiga adalah persalinan yang paling aman. Sebaran preeklampsia terjadi pada masa kehamilan dikutip The New England Journal of Medicine tercatat bahwa pada kehamilan pertama resiko terjadi preeklampsia 3, 9\%, kehamilan kedua 1, $7 \%$, dan kehamilan ketiga. Penelitian Suyati (2011) dikatakan bahwa ada hubungan yang signifikan secara statistik antara paritas ibu dengan kejadian preeklamsia eklamsi dengan hasil $\mathrm{p}$ value 0,007 dan $\mathrm{OR}=3,545$. Hasil penelitian Heny Noviyanti (2010) dengan uji statistik didapat nilai $\mathrm{p}$ value 0,000 kurang dari alpha $(0,05)$ dan $\mathrm{OR}=5,1$ dengan demikian ada hubungan antara paritas ibu dengan kejadian preeklamsia dan pada primigravida memiliki peluang 5,1 kali mengalami preeklamsia. Frekuensi preeklamsia lebih tinggi terjadi pada primigravida dari pada multigravida. Teori Beer mengatakan bahwa preeklamsia eklamsia banyak terjadi pada ibu primigravida yang terpapar villi korialis untuk pertama kali karena pembentukan sel endotel vaskuler pada plasenta belum sempurna. Berdasarkan teori immunologik yang disampaikan Sudhaberata, preeklamsia pada primigravida terjadi dikarenakan pada kehamilan pertama terjadi pembentukan blocking antibodies terhadap antigen tidak sempurna. Selain itu menurut Angsar pada kehamilan pertama terjadi pembentukan Human Leucocyte Antigen Protein G (HLA) yang berperan penting dalam modulasi respon immune, sehingga ibu menolak hadiensil konsepsi (plasenta) atau terjadi intoleransi ibu terhadap plasenta sehingga menyebabkan preeklamsia. Teori lain mengatakan kejadian preeklamsia makin besar pada kehamilan dan persalinan yang sering, dimana pada multigravida keempat atau lebih terjadi perubahan pada jaringan alat- alat kandungan yang berkurang elastis 1, 8\%. (Kurniasari, JURNAL and 2015, 2015).

\section{Hubungan obesitas dengan kejadian preeklampsia pada ibu bersalin di Ruang Bersalin RS SMC Tasikmalaya}

Berdasarkan tabel 3 diatas dapat dilihat bahwa nilai $\mathrm{p}=0,038$, yaitu $<0,05$ sehingga dapat disimpulkan bahwa terdapat hubungan antara obesitas dengan kejadian preeklampsia pada ibu bersalin. Penelitian ini sejalan dengan penelitian Quedarusman yang menunjukkan bahwa kelompok IMT obesitas berisiko 5 kali lebih besar untuk menderita preeklampsia dibandingkan kelompok IMT normal $(\mathrm{OR}=5,06 \quad 95 \% \quad \mathrm{IK}=1,46-12,67)$. Penelitian yang dilakukan oleh James et al.13 menyatakan bahwa berat badan berlebihan pada wanita hamil berhubungan dengan pre-eklampsia. Pada penelitian yang dilakukan Mark et al. dilaporkan bahwa obesitas pada kehamilan berhubungan dengan peningkatan morbiditas pada ibu dan bayi (Dumais, Lengkong and Mewengkang, 2016). Penelitian ini berbeda dengan penelitian Langelo yang menunjukkan bahwa tidak ada hubungan obesitas dengan kejadian preeklampsia. (Quedarusman, Wantania and Kaeng, 2013). Penelitian ini sesuai dengan teori yang menyatakan bahwa Obesitas disebabkan oleh banyak faktor seperti faktor genetik, gangguan metabolik, dan konsumsi makanan yang berlebihan, makin gemuk seseorang makin banyak pula jumlah darah yang terdapat di dalam tubuh yang berarti makin berat pula fungsi pemompaan jantung. Sehingga dapat menyumbangkan terjadinya preeclampsia (Nursal, Tamela and Fitrayeni, 2015, pp. 38-44). Diharapkan supaya ibu hamil memakan makanan yang sehat serta menjaga pola makan yang teratur, serta melakukan diet seimbang, sehingga tidak terjadi peningkatan berat badan yang berlebihan saat kehamilan. Petugas kesehatan sebaiknya memberikan penerangan tentang manfaat istirahat dan tidur, ketenangan, serta pentingnya mengatur diet rendah garam, lemak, serta karbohidrat dan tinggi protein, guna menghindari kenaikan berat badan yang berlebihan. 
Indeks Massa Tubuh (IMT) atau Body Mass Index (BMI) merupakan alat atau cara yang sederhana untuk memantau status gizi orang dewasa, khususnya yang berkaitan dengan kekurangan dan kelebihan berat badan atau obesitas. Batas ambang IMT ditentukan dengan merujuk ketentuan FAO/WHO, Disebutkan bahwa batas ambang normal IMT untuk perempuan adalah : 18,7-23,8.dikatakan overweight atau obesitas bila IMT > 25,1. (Dien, Mulyadi and Kundre, 2014)

\section{Hubungan riwayat kesehatan dengan kejadian preeklampsia pada ibu bersalin di Ruang Bersalin RS SMC Tasikmalaya \\ Salah satu faktor predisposisi} terjadinya pre-eklampsia atau eklampsia adalah adanya riwayat hipertensi kronis, atau penyakit vaskuler hipertensi sebelumnya (hipertensi esensial) serta diabetes mellitus (Astuti, 2015).

Tabel 4 menjelaskan bahwa dari 6 responden yang riwayat kesehatannya termasuk berisiko, 3 (50\%) orang diantaranya mengalami kejadian preeclampsia sedangkan $3(50 \%)$ lainnya tidak mengalami preeclampsia, dan dari 54 responden yang riwayat kesehatannya termasuk dalam kategori tidak berisiko, 27 $(50 \%)$ orang diantaranya mengalami kejadian preeclampsia sedang 27(50\%) orang tidak mengalami preeclampsia. Adapun nilai $p$-value yang diperoleh sebesar 1,000 lebih besar dari 0,05 yang artinya tidak terdapat hubungan antara riwayat kesehatan dengan kejadian preeklampsia pada ibu bersalin.

Hasil penelitian ini sejalan dengan penelitian yang dilakukan oleh Nursal dkk tahun 2014 di RSUP Dr. M Jamil Padang yang menunjukkan bahwa tidak terdapat hubungan yang bermakna antara riwayat diabetes mellitus dengan kejadian preeclampsia (Nursal, Tamela and Fitrayeni, 2015, pp. 38-44)

\section{E. Hubungan kadar kalsium dengan kejadian preeklampsia pada ibu bersalin di Ruang Bersalin RS SMC Tasikmalaya}

Tabel 5 menjelaskan bahwa dari 32 responden yang kalsiumnya termasuk normal, $22(68,8 \%)$ orang diantaranya mengalami kejadian preeclampsia sedangkan $10(31,3 \%)$ orang lainnya tidak mengalami preeclampsia, dan dari 28 responden yang kalsiumnya termasuk dalam kategori tidak normal, $8(28,6 \%)$ orang diantaranya mengalami kejadian preeclampsia sedang $20(71,4 \%)$ orang tidak mengalami preeclampsia. Adapun nilai p-value yang diperoleh sebesar 0,002 lebih kecil dari 0,05 yang artinya terdapat hubungan antara kadar kalsium ibu bersalin dengan kejadian preeklampsia pada ibu bersalin. Selama kehamilan kadar kalsium total dalam serum turun akibat dari kadar albumin yang turun selama kehamilan akan tetapi kadar kalsium yang terionisasi tidak mengalami perubahan rerata kadar kalsium total darah pada wanita. Hasil akan menurun sesuai dengan bertambahnya umur kehamilan yaitu: trimesrter I: 9,6 $\pm 0,26 \mathrm{mg} / \mathrm{dL}$, trimester II: $9,12 \pm 0,28 \mathrm{mg} / \mathrm{dL}$, dan pada trimester III: $8,92 \pm 0,32 \mathrm{mg} / \mathrm{dL}$. (Christhoper S.K, 2012) Nilai normal kadar kalsium adalah sebagai berikut:

a. Kalsium total $8,9-109 \mathrm{mg} / \mathrm{dL}(2,2-2,5$ $\mathrm{mmol} / \mathrm{L}$ ),

b. Kalsium yang terikat protein $4,1-4,7$ $\mathrm{mg} / \mathrm{dL}(1,0 .-1,2 \mathrm{mmol} / \mathrm{L})$;

c. Kalsium yang terionisasi 4,5-5,6 $\mathrm{mg} / \mathrm{dL}(1,0-1,2 \mathrm{mmol} / \mathrm{L})$;

d. Kalsium kompleks 0,7-0,8 $\mathrm{mg} / \mathrm{dL}$ $(0,18-1,2 \mathrm{mmol} / \mathrm{L})$.

e. Nilai untuk kalsium total dibawah 8,9 $\mathrm{mg} / \mathrm{dL} \quad(2,2 \mathrm{mmol} / \mathrm{L})$ menunjukkan hipokalsemia dan nilai diatas 10,1 $\mathrm{mg} / \mathrm{dL} \quad(2,5 \mathrm{mmol} / \mathrm{L})$ menunjukkan hiperkalsemia.

F. Faktor-faktor yang berhubungan dengan kejadian preeklampsia pada ibu bersalin di Ruang Bersalin RS SMC Tasikmalaya

Dari berbagai faktor yang berhubungan dengan kejadian preeklampsia secara signifikan adalah variabel kalsium dengan nilai odd ratio sebesar 7,237 yang artinya faktor kalsium mempunyai peluang sebesar 7,237 kali menyebabkan kejadian preeklampsia pada ibu bersalin di Ruang VK RS SMC Tasikmalaya.

Peranan kalsium yang rendah pada ibu hamil dalam menyebabkan preeklamsia 
dapat dijelaskan melalui beberapa mekanisme, di antaranya bila kadar kalsium rendah maka akan meningkatkan pengeluaran hormon paratiroid dan selanjutnya menyebabkan peningkatan kalsium intraseluler pada otot polos vaskuler. Peningkatan kalsium intraseluler pada otot polos vaskuler ini akan menyebabkan peningkatan resistensi vaskuler dan vasokonstriksi yang akan memicu peningkatan tekanan darah.

Mekanisme lain dengan cara merangsang pengeluaran renin yang akan meningkatkan angiotensin II dan akan meningkatkan tekanan darah. Kadar kalsium yang rendah ini juga dapat menurunkan kadar magnesium darah dan selanjutnya memicu vasokonstriksi otot polos vaskular serta akan menurunkan efek endothelial nitric oxide synthase (eNOS), suatu enzim yang tergantung kalsium sehingga menghambat vasodilatasi pembuluh darah. Hambatan vasodilatasi ini juga disebabkan karena penurunan prostasiklin di sirkulasi. Prostasiklin merupakan enzim yang tergantung kalsium dan vasodilator yang poten (Harini, Novara and Sutrisno, 2018).

Beberapa penelitian melaporkan kadar kalsium darah yang lebih rendah pada preeklamsia dibandingkan kelompok kontrol atau normotensi. Rendahnya kadar kalsium pada ibu hamil dapat disebabkan oleh proses hemodilusi, sekresi urin yang meningkat, transfer mineral kalsium dari ibu ke janin yang meningkat serta intake rendah kalsium pada ibu hamil. Keterbatasan pada penelitian ini antara lain tidak diteliti asupan kalsium pada ibu sehingga tidak diketahui apakah kadar kalsium yang rendah ini disebabkan oleh intake yang rendah atau sebab yang lain.

\section{KESIMPULAN}

Berdasarkan hasil analisis yang telah disajikan, maka peneliti mengambil kesimpulan bahwa Terdapat hubungan antara usia, obesitas, dan kadar kalsium terhadap kejadian preeklampsia pada ibu bersalin di ruang bersalin RS SMC Tasikmalaya. Diharapkan penelitian ini dapat berguna bagi tenaga kesehatan untuk meningkatkan promotif dan preventif dengan penyuluhan dan sosialisasi mengenai faktor-faktor yang beresiko meningkatkan kejadian preeklampsia sehingga ibu dapat menjalani kehamilan dan persalinan yang sehat.

\section{DAFTAR PUSTAKA}

Indrawati, (2010) Panduan Perawatan Kehamilan. Atma

Astuti, S. F. (2015) Faktor-Faktor Yang Berhubungan Dengan Kejadian Preeklampsia Kehamilandi Wilayah Kerja Puskesmaspamulang Kota Tangerang Selatan Tahun 2014-2015.

Dien, N. G., Mulyadi And Kundre, R. M. (2014) 'Hubungan Indeks Massa Tubuh (IMT) Dengan Tekanan Darah Pada Penderita Hipertensi Di Poliklinik Hipertensi dan Nefrologi Blu Rsup Prof. Dr. R. D. Kandou Manado Available at: https://media.neliti.com/media/publication s/114369-ID-hubungan-indeks-massatubuh-imt-dengan-t.pdf.

Dumais, C. ., Lengkong, R. A. and Mewengkang, M. E. (2016) 'Hubungan obesitas pada kehamilan dengan preeklampsia', e-CliniC, 4(1). doi: 10.35790/ecl.4.1.2016.11686.

Harini, I. M., Novara, T. and Sutrisno, S. (2018) 'Perbedaan Kadar Kalsium Darah pada Kehamilan Preeklamsia dengan Kehamilan Normotensi', Jurnal Kedokteran Brawijaya, 30(2), p. 109. doi: 10.21776/ub.jkb.2018.030.02.6.

Kurniasari, D., JURNAL, F. A.-H. and 2015, undefined (2015) 'Hubungan Usia, Paritas Dan Diabetes Mellitus Pada Kehamilan Dengan Kejadian Preeklamsia Pada Ibu Hamil Di Wilayah Kerja Puskesmas Rumbia Kabupaten', Ejurnalmalahayati.Ac.Id, 9(3), pp. 142150. Available at: http://ejurnalmalahayati.ac.id/index.php/h olistik/article/view/232.

Nursal, D. G. A., Tamela, P. and Fitrayeni, F. (2015) 'Faktor Risiko Kejadian Preeklampsia Pada Ibu Hamil Di Rsup Dr. M. Djamil Padang Tahun 2014', Jurnal Kesehatan Masyarakat Andalas, 10(1), p. 38. doi: 10.24893/jkma.10.1.38-44.2015.

Quedarusman, H., Wantania, J. and Kaeng, J. J. (2013) 'Hubungan Indeks Massa Tubuh Ibu Dan Peningkatan Berat Badan Saat Kehamilan Dengan Preeklampsia', Jurnal e-Biomedik, 1(1), pp. 305-311. doi: 10.35790/ebm.1.1.2013.4363. 